\title{
Paleo ice flow and subglacial meltwater dynamics in Pine Island Bay, West Antarctica
}

\author{
F. O. Nitsche ${ }^{1}$, K. Gohl ${ }^{2}$, R. D. Larter ${ }^{3}$, C.-D. Hillenbrand ${ }^{3}$, G. Kuhn ${ }^{2}$, J. A. Smith ${ }^{3}$, S. Jacobs ${ }^{1}$, J. B. Anderson ${ }^{4}$, and \\ M. Jakobsson ${ }^{5}$ \\ ${ }^{1}$ Lamont-Doherty Earth Observatory of Columbia University, Palisades, New York, USA \\ ${ }^{2}$ Alfred Wegener Institute for Polar and Marine Research, Bremerhaven, Germany \\ ${ }^{3}$ British Antarctic Survey, Cambridge, UK \\ ${ }^{4}$ Department of Earth Sciences, Rice University, Houston, Texas, USA \\ ${ }^{5}$ Department of Geological Sciences, Stockholm University, Stockholm, Sweden
}

Correspondence to: F. O. Nitsche (fnitsche@1deo.columbia.edu)

Received: 9 August 2012 - Published in The Cryosphere Discuss.: 4 October 2012

Revised: 7 January 2013 - Accepted: 11 January 2013 - Published: 8 February 2013

\begin{abstract}
Increasing evidence for an elaborate subglacial drainage network underneath modern Antarctic ice sheets suggests that basal meltwater has an important influence on ice stream flow. Swath bathymetry surveys from previously glaciated continental margins display morphological features indicative of subglacial meltwater flow in inner shelf areas of some paleo ice stream troughs. Over the last few years several expeditions to the eastern Amundsen Sea embayment (West Antarctica) have investigated the paleo ice streams that extended from the Pine Island and Thwaites glaciers. A compilation of high-resolution swath bathymetry data from inner Pine Island Bay reveals details of a rough seabed topography including several deep channels that connect a series of basins. This complex basin and channel network is indicative of meltwater flow beneath the paleo-Pine Island and Thwaites ice streams, along with substantial subglacial water inflow from the east. This meltwater could have enhanced ice flow over the rough bedrock topography. Meltwater features diminish with the onset of linear features north of the basins. Similar features have previously been observed in several other areas, including the Dotson-Getz Trough (western Amundsen Sea embayment) and Marguerite Bay (SW Antarctic Peninsula), suggesting that these features may be widespread around the Antarctic margin and that subglacial meltwater drainage played a major role in past ice-sheet dynamics.
\end{abstract}

\section{Introduction}

Response of the Antarctic ice sheets to changing climate conditions is one of the largest uncertainties in the prediction of future sea-level (IPCC, 2007). Much of that response will depend on the behaviour of large ice streams, the main conduits of ice flux from the inner portions of the ice sheets to the coast (Bentley, 1987; Bennett, 2003). Understanding how ice streams behaved in the past can improve predictions of future changes (e.g., Stokes and Clark, 2001; Anderson et al., 2002; Vaughan and Arthern, 2007; Livingstone et al., 2012).

The West Antarctic Ice Sheet (WAIS) is considered especially vulnerable, because the WAIS is mainly grounded below sea level (Hughes, 1973), with ice shelf margins exposed to "warm" Southern Ocean water masses (Joughin and Alley, 2011). About 25-35\% of the WAIS is currently draining into the Amundsen Sea, mostly through the Pine Island and Thwaites glaciers (Drewry et al., 1982; Rignot et al., 2008). These ice streams are potential weak points in the ice sheet because they occupy troughs that become steadily deeper towards the WAIS interior and are buttressed by relatively small ice shelves (Hughes, 1973; Vaughan et al., 2006). Theoretical studies have concluded that ice grounding lines are unstable on such reverse gradients and, therefore, once retreat starts it may proceed rapidly (Weertman, 1974; Schoof, 2007), as recently observed under the Pine Island Ice Shelf (Jenkins et al., 2010). 
Interest in the Amundsen Sea sector has increased since studies showed that Pine Island and Thwaites Glaciers are presently thinning significantly (Wingham et al., 1998; Shepherd et al., 2001) and that their flow velocity has increased up to $4000 \mathrm{~m} \mathrm{yr}^{-1}$ (Rignot and Thomas, 2002; Joughin et al., 2010). These changes appear to be caused by strong melting under their floating extensions, driven by the intrusion of relatively warm Circumpolar Deep Water (CDW) onto the continental shelf (Jacobs et al., 1996; Jenkins et al., 1997; Hellmer et al., 1998; Rignot and Jacobs, 2002; Shepherd et al., 2004; Jacobs et al., 2011; Pritchard et al., 2012). As a consequence, these ice streams now account for an ice loss of $\sim 50-85 \mathrm{Gt} \mathrm{yr}^{-1}$ (Rignot et al., 2008; Pritchard et al., 2009) and already contribute to current sea-level rise (Shepherd and Wingham, 2007; Rignot et al., 2011).

While those observations document ice stream change over the last few decades, detailed marine geological studies of the previously glaciated seafloor have established a framework of past ice sheet extent, flow pattern, and grounding line retreat in the Amundsen Sea sector since the Last Glacial Maximum (LGM), defined as the time interval 23$19 \mathrm{kyr}$ before present (BP) in the Southern Hemisphere (Livingstone et al., 2012). The regional bathymetry shows a large cross-shelf trough system that extends from the present Thwaites and Pine Island ice shelves to the outer continental shelf (Fig. 1; Nitsche et al., 2007). Detailed studies of this trough system revealed that it was occupied by a paleo ice stream and documented an episodic retreat soon after the LGM on the outer and middle continental shelf (Graham et al., 2010; Jakobsson et al., 2011, 2012).

The grounding line of the paleo-Pine Island Ice Stream shifted from the outer shelf to the central shelf by $\sim 16400 \mathrm{cal} \mathrm{yr}^{-1} \mathrm{BP}$, followed by another landward shift that left the central shelf covered by an ice shelf from $\sim 12300$ to $\sim 10600 \mathrm{cal} \mathrm{yr}^{-1} \mathrm{BP}$ (Lowe and Anderson, 2002; Kirshner et al., 2012). An episode of ice shelf collapse believed to have been triggered by warm deep water incursion onto the shelf prompted rapid grounding line retreat towards the inner shelf (Kirshner et al., 2012).

The retreat history and dynamics of the paleo ice stream in inner Pine Island Bay is less well understood. New radiocarbon dates from sediment cores located $\sim 93 \mathrm{~km}$ from the modern grounding line of Thwaites Glacier and $\sim 112 \mathrm{~km}$ from that of Pine Island Glacier suggest minimum ages for grounded ice retreat of $\sim 10350$ and $\sim 11660 \mathrm{cal} \mathrm{yr}^{-1} \mathrm{BP}$, respectively (Hillenbrand et al., 2013). Cosmogenic surface exposure ages on erratics from the flanks of Pine Island Glacier in the Hudson Mountains yielded a record of progressive ice thinning for the last $\sim 14.5 \mathrm{ka} \mathrm{BP}$ that is consistent with the marine record, although the few available dates do not provide much detail about variations in thinning rates or different episodes of retreat of the Pine Island-Thwaites drainage basin (Johnson et al., 2008).

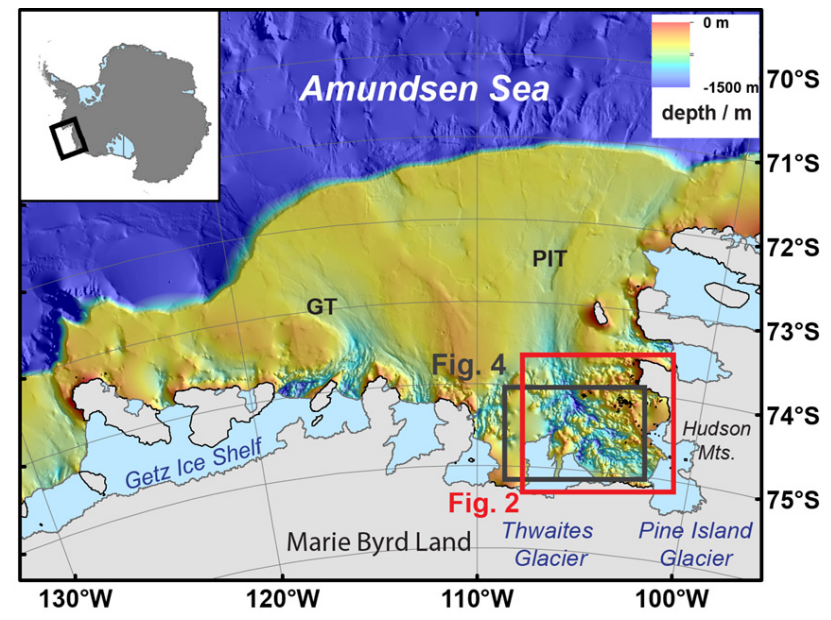

Fig. 1. Bathymetry map of the Amundsen Sea shelf with the red rectangle marking the location of the Pine Island Bay study area in Figs. 2 and 4 (based on Nitsche et al., 2007). PIT marks the Pine Island Trough system and GT the Dotson-Getz Trough System.

Published bathymetry data from Pine Island Bay revealed a complex seafloor dominated by deep bedrock basins with local patches of a generally thin sedimentary cover (Fig. 2b) (Kellogg and Kellogg, 1987b; Lowe and Anderson, 2002). Lowe and Anderson (2002) identified a series of detailed morphological features, which they interpreted as gouges, $\mathrm{p}$ forms and drumlins formed by glacial erosion (their zones 1, 2; see Fig. 2b) and mega-scale glacial lineations formed by ice streams overriding sediment deposits (zone 3). The change in seafloor morphology was linked to changes in subglacial substrate from crystalline bedrock to sediment near the inner to middle shelf transition (Wellner et al., 2001; Lowe and Anderson, 2002). These data also led to the first identification of subglacial meltwater channels on the Antarctic continental shelf (Lowe and Anderson, 2003). Both the presence of subglacial meltwater and the variability of subglacial substrate could have significantly influenced ice stream behaviour, as lubricated beds and sedimentary substrate tend to allow faster ice flow, whereas dryer beds and exposed bedrock may result in higher bed friction (Bennett, 2003). A detailed understanding of the origin of the subglacial features, configurations and substrates could, thus, provide critical information on the dynamics of these ice streams.

Here we present extensive new high-resolution swath bathymetry with almost complete coverage of inner Pine Island Bay (Figs. 1, 2). These data reveal networks of channels eroded by subglacial meltwater, with possible implications for ice flow mechanisms and subglacial water sources of the Pine Island and Thwaites Ice Streams. 


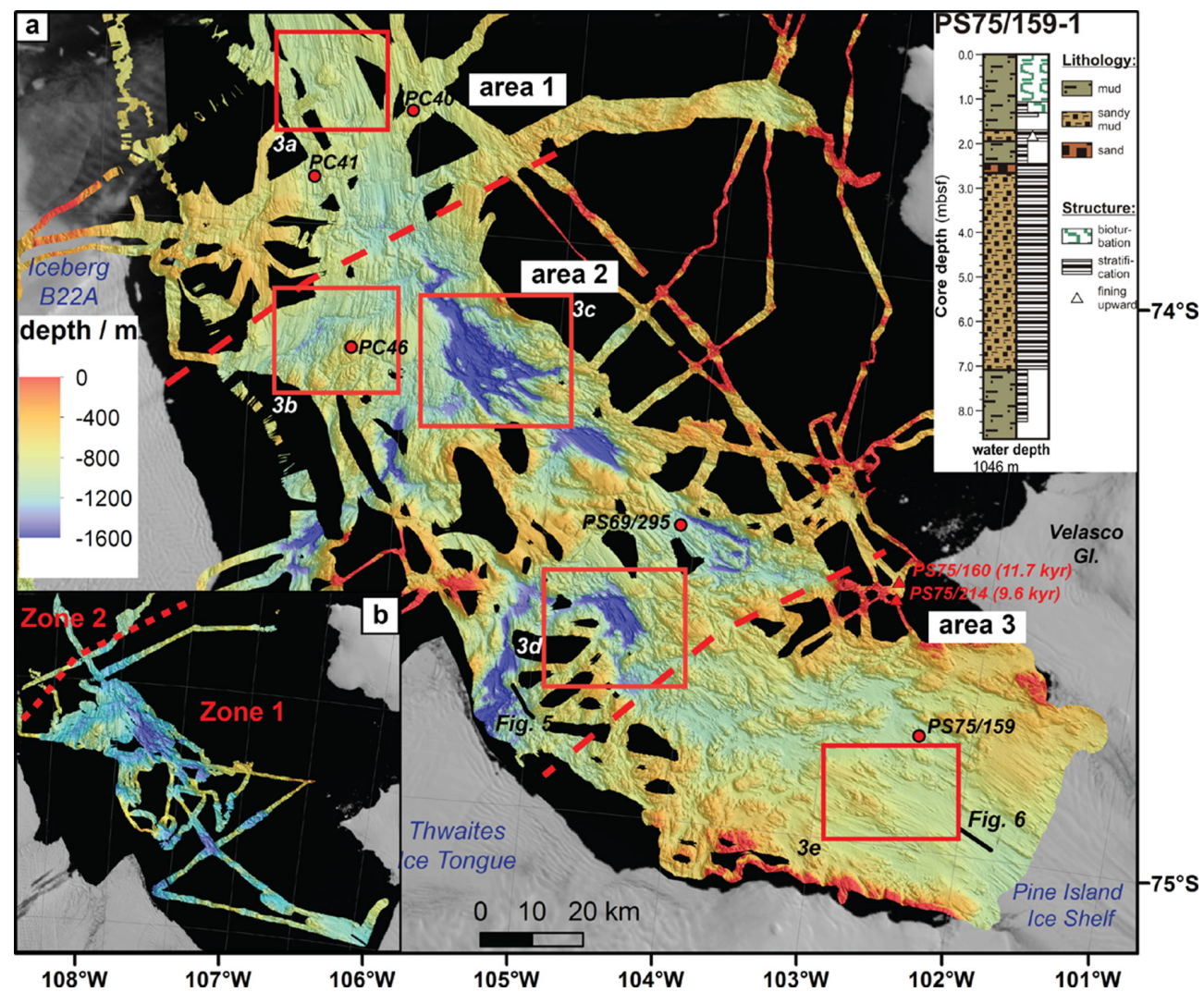

Fig. 2. (a) High-resolution bathymetry map of Pine Island Bay with artificial sun-illumination from the NE. Many of the larger gaps in the data set are due to icebergs at the time of data collection. Dashed red lines mark boundaries between morphological distinct areas 1 to 3 . Red boxes mark detailed views shown in Fig. 3. Red dots mark sediment core locations. The inset in the upper right corner shows lithology of sediment core PS75/159. Background image is from the Landsat Image Mosaic of Antarctica (LIMA). (b) Multibeam bathymetry data from the same area published previously by Lowe and Anderson $(2002,2003)$. Red dotted line marks the boundary between the geomorphic zones 1 and 2 defined by Lowe and Anderson (2002).

\section{Data and methods}

Since 1999, several expeditions have obtained swath bathymetry data in the Pine Island Bay area (Table 1). In particular, unusually favourable sea ice and weather conditions in early 2009 and 2010 permitted the acquisition of high-quality data for most of Pine Island Bay directly seaward of the Pine Island Ice Shelf. Operating equipment included various Seabeam, Kongsberg, and Atlas Hydrosweep swath sonar systems (Table 1). Data were corrected for sound velocity based on numerous CTD and XBT casts. The raw soundings were processed and edited on-board using MB-system (Caress and Chayes, 1996) on R/V Nathaniel B. Palmer and RRS James Clark Ross, and CARIS/HIPS (Hydrographic Information Processing System) on R/V Polarstern and IB Oden.

We combined the different swath bathymetry data and generated a new bathymetry grid of Pine Island Bay at $35 \mathrm{~m}$ resolution using mbgrid from MB-system. The final grid was imported into ESRI's ArcGIS geographic information system for further analysis.
Simultaneously with its multibeam bathymetry survey, R/V Polarstern acquired PARASOUND sub-bottom profiler data. The PARASOUND system is a hull-mounted subbottom profiler that transmits two primary frequencies at around $18 \mathrm{kHz}$ to produce a parametric secondary pulse with frequencies selectable between $2.5-5.5 \mathrm{kHz}$ (Grant and Schreiber, 1990). We used a $4 \mathrm{kHz}$ signal and processed it including signal correlation, basic filtering $(2-6 \mathrm{kHz}$ bandpass), amplitude normalisation and noise reduction. Maximum penetration depths were digitised by hand and georeferenced using the ship GPS navigation (Rackebrandt, 2006). Sub-bottom data collected on other cruises listed in Table 1 were not available for this study or were of poor quality caused by the rough terrain.

Multichannel seismic profiling in proximity to the ice shelf edge of the Pine Island Glacier was conducted from R/V Polarstern in 2010 with a source array consisting of two generator-injector (GI) air guns shot every $6 \mathrm{~s}$, and recorded with a $600 \mathrm{~m}$ long analogue hydrophone streamer of 96 channels. We applied standard seismic data processing including a predictive deconvolution filter for the removal of the 
Table 1. Expeditions with multibeam data used for this compilation.

\begin{tabular}{lllll}
\hline Cruise & Ship & Year & System & PI \\
\hline NBP9902 $^{\mathrm{a}}$ & NB Palmer & 1999 & SeaBeam 2112 & J. Anderson (Rice U.) \\
NBP0001 $^{\mathrm{a}}$ & NB Palmer & 2000 & SeaBeam 2112 & S. Jacobs (LDEO) \\
ANT-XXIII/4 & Polarstern & 2006 & HydroSweep DS2 & K. Gohl (AWI) \\
NBP0702 $^{\mathrm{a}}$ & NB Palmer & 2007 & EM 120 & S. Jacobs (LDEO) \\
JR179 $^{\text {OSO0708 }}$ & James C. Ross & 2008 & EM 120 & R. Larter (BAS) \\
NBP0901 $^{\mathrm{a}}$ & Oden & 2008 & EM 120 & M. Jakobsson (U. Stockholm) \\
NNT-XXVI/3 & Polarstern & 2009 & EM 120 & S. Jacobs (LDEO) \\
\hline
\end{tabular}

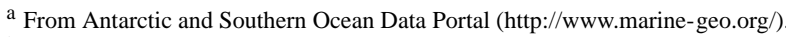

b From Oden Mapping Data Repository (http://oden.geo.su.se/)

receiver and source ghost signal and a bandpass filter of 15$100 \mathrm{~Hz}$.

\section{Results}

The compilation of swath bathymetry data resulted in a comprehensive $35 \mathrm{~m}$-grid that covers large parts of Pine Island Bay (Fig. 2). The grid includes most of the main paleo-ice stream trough while data gaps remain in shallow areas northeast of the trough and around Iceberg B22A, which was formerly an ice tongue extending from Thwaites Glacier.

The overall seafloor morphology varies significantly over the mapped region, but three areas with different seabed characteristics can be distinguished. The seafloor morphology of the northernmost study area 1 (north of $\sim 74^{\circ} \mathrm{S}$ ) is characterised by moderate relief with water depths in the range $500-1100 \mathrm{~m}$, gradually shoaling seaward and dominated by linear features (Fig. 2). This pattern continues northward towards the mid-shelf, where it changes into megascale glacial lineations (MSGL) interrupted by grounding zone wedges as described by Graham et al. (2010) and Jakobsson et al. (2012). Area 2 adjacent to the southeast, between $74.8^{\circ} \mathrm{S}$ and $74^{\circ} \mathrm{S}$, is characterised by a very rugged terrain with shallow ridges and deep (1400-1650 m) basins. The innermost section (area 3) directly in front of the Pine Island Ice Shelf has a moderate relief with water depths between 500 and $1000 \mathrm{~m}$, clearly defined parallel, linear features orientated along the trough axis, and a few ridges and mounds orientated oblique to the trough axis.

\subsection{Linear features}

Pine Island Bay is characterised by various types of linear subglacial features (Fig. 3). The central part of area 1 is dominated by drumlin-shaped ridges, which are elongated and tear-shaped, with some "whaleback" ridges and crag-and-tail features (Fig. 3a). These mostly parallel or sub-parallel features are $25-80 \mathrm{~m}$ high, $300-1500 \mathrm{~m}$ wide and between 1500 and $8000 \mathrm{~m}$ long. They taper from south to north, thus, indicating paleo-ice flow in that direction (Bennett and Glasser,
1996). Crossing acoustic sub-bottom profiles demonstrate that the sedimentary cover of these bedforms is very thin or absent (Figs. 4, 5) and suggests formation of the cragand-tail and drumlin shapes in a hard substrate such as stiff till or rock. The absence of a thick sediment cover is consistent with evidence from seismic profiles showing that the seafloor south of $\sim 73.5^{\circ} \mathrm{S}$ is mainly underlain by acoustic basement interpreted as crystalline bedrock (Lowe and Anderson, 2002, 2003; Uenzelmann-Neben et al., 2007). This has also been observed in inner sections of several other Antarctic paleo-ice stream troughs (e.g., Wellner et al., 2001; Ó Cofaigh et al., 2002; Larter et al., 2009). Sediment cores from area 1 recovered thin layers $(<2.2 \mathrm{~m})$ of mud intercalated with diamicton (site PC40; Lowe and Anderson, 2003) and silty diamicton (site PC41; Lowe and Anderson, 2002), respectively (see Fig. 2 for locations). The occurrence of diamicton in such shallow depths also indicates that these features were probably formed subglacially.

The central area 2 contains fewer drumlin-shaped features. Instead the data show widespread grooves, mainly on ridges and bedrock highs (e.g., Fig. 3b, c, d). Most of the grooves are 2-10 $\mathrm{m}$ deep, $50-150 \mathrm{~m}$ wide and incised into the underlying substrate. They generally follow the orientation of the main trough and are likely to have been created by ice flowing across topographic highs (Bennett and Glasser, 1996).

The smoother, innermost area 3 is also dominated by linear features, here $10-20 \mathrm{~m}$ high, $200-400 \mathrm{~m}$ wide and 2-8 km long (Fig. 3e). In contrast to the other regions, many of these lineations appear to be depositional, with elongation ratios $>10: 1$ comparable to that of MSGLs (Stokes and Clark, 2001). Several other features are drumlin-shaped, but the lack of good-quality acoustic sub-bottom data from this area precludes attribution of their formation in a sedimentary substrate. However, multichannel seismic data from the southern part of area 3 show that part of this section consists of $>100 \mathrm{~m}$ of sedimentary strata (Fig. 6). Following examples from other Antarctic shelf areas we interpret these features as glacial lineations and drumlins that are more typical for sedimentary substrate (e.g., Wellner et al., 2001; Ó Cofaigh et al., 2002). 


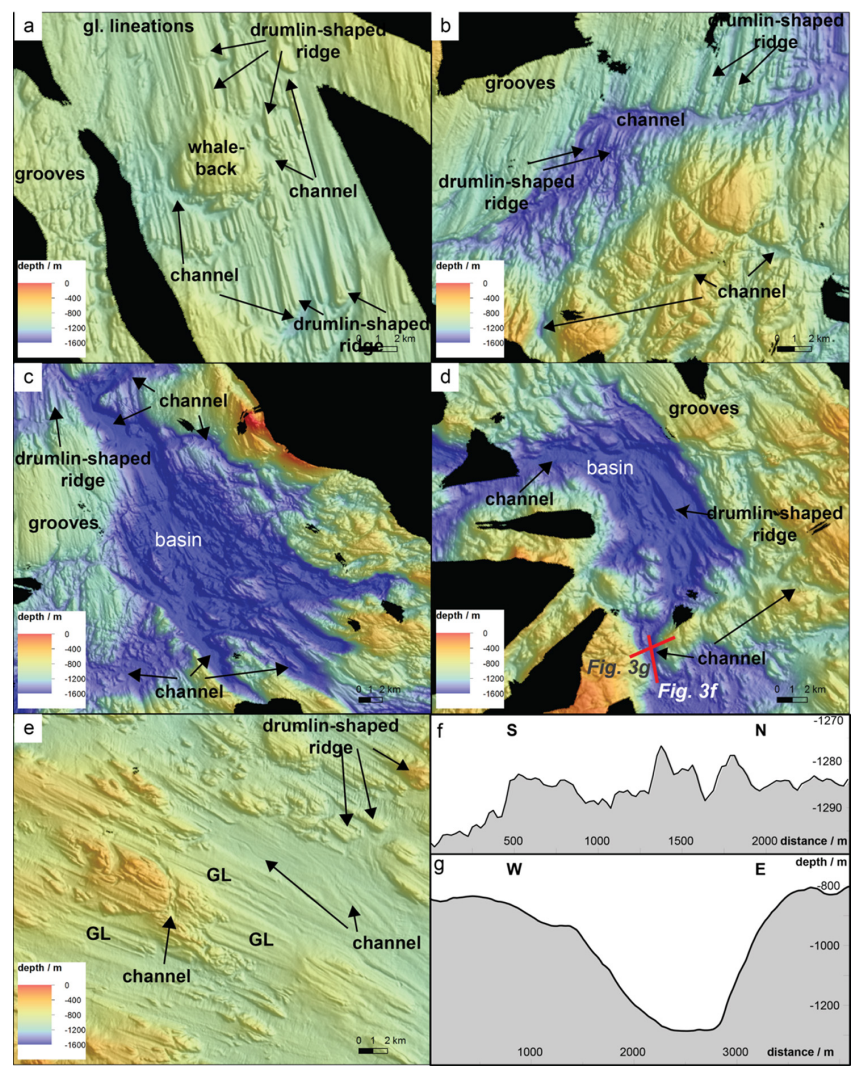

Fig. 3. (a-e) Detailed examples of morphological features including glacial lineations (GL), basins, channels, drumlin-shaped ridges and grooves. (f) Undulating thalweg and (g) cross-section of large channel marked in (d).

The comprehensive data coverage allows us to map the orientation of these linear features in detail (Fig. 7). The parallel and sub-parallel features are oriented from $285-290^{\circ}$ in the inner part of area 3 (Fig. 2) and progressively change in orientation through area $2\left(330-340^{\circ}\right)$ to $350-360^{\circ}$ in outer area 1 . These directions correspond to the general orientation of the paleo-ice stream trough system.

\subsection{Basins}

The dominant morphological features of area 2 are slightly elongated, deep (up to $1650 \mathrm{~m}$ ), and several kilometre wide seafloor depressions more than $300 \mathrm{~m}$ below the surrounding seafloor $(800-1100 \mathrm{~m})$. Often the edges of these basins are marked by steep slopes, which are intersected by numerous channels (Fig. 3c, d). Maximum water depths are several hundred meters greater than near the present ice shelf front (1000-1100 m; Fig. 2a). Lowe and Anderson (2003) have interpreted some of the basins as features initially eroded into bedrock by ice and later modified by meltwater flow. Similar basins have been observed in several other inner shelf locations around Antarctica (Wellner et al., 2006) including

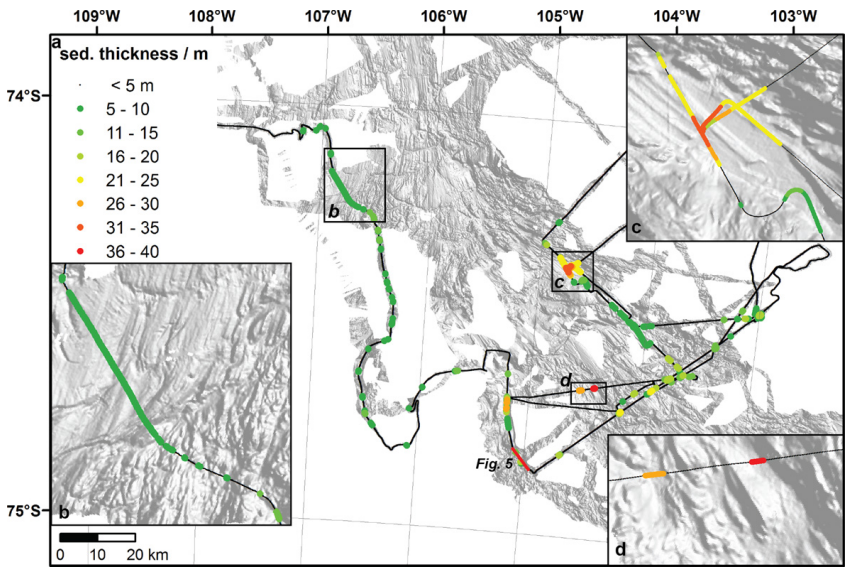

Fig. 4. (a) Sediment thickness (coloured dots) derived from PARASOUND data, modified from Rackebrandt (2006). Black line indicates segments of R/V Polarstern ANT-XXIII/4 ship track where no significant sediment thickness was identified. Multibeam bathymetry data with artificial sun-illumination are shown as background. Details in insets (b), (c), and (d) show that thicker sediment deposits occur mainly in channels, but not in every channel. Location of Fig. 5 is marked by red line.

the Dotson-Getz Trough (Larter et al., 2009), and Marguerite Bay (Anderson and Fretwell, 2008).

The deepest parts of some basins show linear or drumlinshaped features (Fig. 3d), indicating they were filled with grounded ice during previous glaciations. Acoustic subbottom profiles from the inner shelf generally show sediment cover $<5 \mathrm{~m}$ thick, but with localised, $10-40 \mathrm{~m}$ thick sediment pockets in some of the deepest basins (Fig. 4; Rackebrandt, 2006). Seismic lines crossing the northern basins have revealed over $75 \mathrm{~m}(>50 \mathrm{~m})$ of sediment fill in some places (Uenzelmann-Neben et al., 2007), and at least $300 \mathrm{~m}$ of sediment near the Pine Island Ice Shelf edge (Fig. 6). Sediment cores from the basins of area 2 have typically recovered long (up to $10 \mathrm{~m}$ ) sequences of unconsolidated mud and sandy mud, occasionally with a diamicton at the core base (e.g., site PS69/295-1; Ehrmann et al., 2011). These pockets of unconsolidated sediment have likely been deposited since the last retreat of grounded ice from these basins (Smith et al., 2009b).

\subsection{Channels}

The detailed bathymetry shows two types of channels in Pine Island Bay. The first type connects the deep basins and is $200-400 \mathrm{~m}$ deep, $1-2 \mathrm{~km}$ wide, and $10-15 \mathrm{~km}$ long (Figs. 2, 3c, d, f, g). The second type is smaller and more variable in size and geometry, 10-200 m deep, 150-1500 m wide and 2-25 km long (Fig. 3a-e). Most channels of both types are anastomosing with undulating and meandering thalwegs. Channel orientation varies, with some connecting to the main channels and others almost perpendicular 


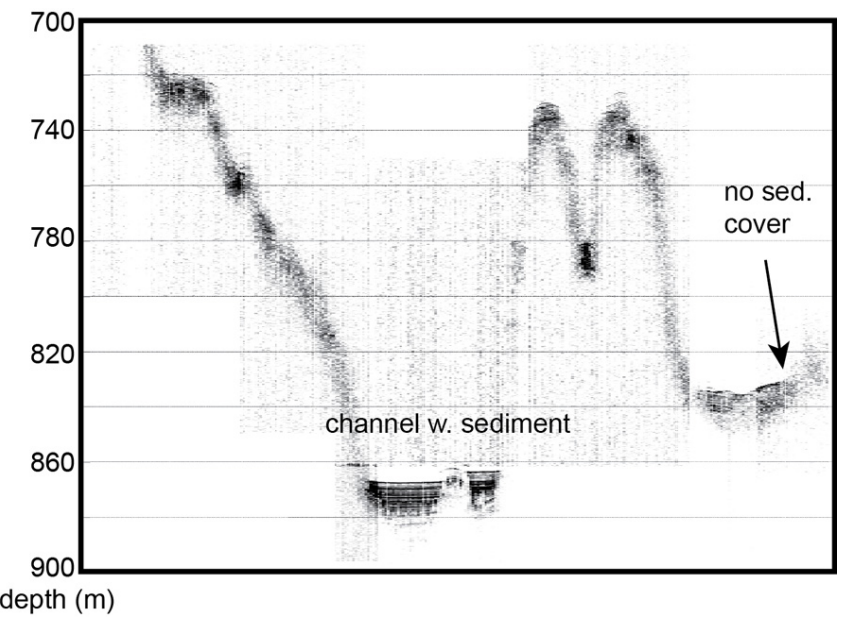

Fig. 5. PARASOUND example showing $\sim 20 \mathrm{~m}$ of sediment fill in the channels and no sediments on slopes and ridges. See Fig. 4 for location.

to the paleo-ice flow defined by glacial lineations (Fig. 7, blue lines). The undulating and meandering geometry of the channels (Fig. 3f) and their oblique orientation with regard to the general trough direction indicate that they were not formed by grounded ice flow. A sediment core from a channel in area 2 (PC 46) recovered a $\sim 0.5 \mathrm{~m}$ thick section of mostly sand and gravel at the top that may have originated from the bed-load of former meltwater flows (Lowe and Anderson, 2003). Similar channels have been observed in inner shelf regions of other paleo-ice stream troughs around Antarctica (e.g., Wellner et al., 2006; Anderson and Fretwell, 2008; Smith et al., 2009b), on previously glaciated margins in the Northern Hemisphere (e.g., Booth and Hallet, 1993; Jorgensen and Sandersen, 2006), and onshore in the Dry Valleys in the Transantarctic Mountains (Lewis et al., 2006).

\subsection{Thickness of unconsolidated sediments}

The maximum sub-bottom penetration depth of the PARASOUND signal in areas 2 and 3 indicates the presence or minimum thickness of unconsolidated sediments (Fig. 4). Most of the track does not show any sedimentary cover, confirming earlier interpretations that the inner Pine Island Bay seafloor consists mostly of a hard substrate, presumably bedrock. However, some channels and basins are characterised by significant sediment infill (>5 m) (Figs. 4c, 5), while other channels are barren of unconsolidated sediments. Since the PARASOUND signal is unlikely to penetrate consolidated stiff till, most sediment layers visible in the PARASOUND data probably correspond to sands, silts and muds that have not been consolidated by overriding ice and, therefore, are likely to be of post-glacial origin. Turbidity currents or other mass transport mechanisms may have concentrated sediment in the deeper basins by scouring and redepositing material from shallower shelf areas or other channels, but the available acoustic sub-bottom data are still too sparse to clearly verify such a pattern.

\section{Discussion}

This new compilation of high-resolution bathymetry from Pine Island Bay allows a more detailed analysis and interpretation of ice flow and subglacial meltwater drainage than in previous studies (Kellogg and Kellogg, 1987b; Lowe and Anderson, 2002, 2003).

\subsection{Paleo-ice flow}

Linear morphological features observed in Pine Island Bay are typical of Antarctic paleo-ice stream troughs (e.g., Canals et al., 2000; Ó Cofaigh et al., 2002; Wellner et al., 2006; Dowdeswell et al., 2007). Their orientation can be interpreted as the direction of past ice flow (Boulton and Clark, 1990; Clark, 1993). In area 3, i.e., in front of the present Pine Island Ice Shelf, the past ice flow was in the same direction as the present flow of Pine Island Glacier. The flow direction turned slightly northward in area 2 at the confluence with the paleo-ice stream extending offshore from Thwaites Glacier, and then followed the outline of the main trough (Fig. 7, black lines).

A few lineations at the southern edge of the data between $104^{\circ} \mathrm{W}$ and $106^{\circ} \mathrm{W}$ indicate that streaming ice flow also occurred in the area between Pine Island and Thwaites glaciers, which indicates that during the LGM the ice streams were wider than today or, less likely, their trunks shifted their locations.

The flow lines joining the main flow north of $\sim 74.5^{\circ} \mathrm{S}$ document the confluence of Pine Island and Thwaites glaciers, and farther north the convergence with Smith Glacier (Nitsche et al., 2007; Graham et al., 2010). This flow convergence would have resulted in an increase in flow speed, which is suggested by the higher elongation ratios of lineations and other subglacial bedforms at this point, compared to those of features further south.

Previous studies of paleo-ice stream troughs on the Antarctic continental shelf have shown that the innermost shelf usually consists of rugged terrain similar to the central part of Pine Island Bay, i.e., area 2, and that this morphology often changes in the mid-shelf region towards a smoother topography and well-defined, more elongated subglacial lineations (MSGL) (see review in Livingstone et al., 2012). This change usually coincides with the transition from exposed bedrock on the inner shelf towards sedimentary substrate on the middle-outer shelf, the rugged terrain resulting from subglacial bedrock erosion of the sediment cover (Wellner et al., 2006). Based on these differences in seafloor morphology and underlying seismic character, Lowe and Anderson (2002) distinguished two zones in Pine Island Bay. They describe their innermost zone 1 as being dominated by 


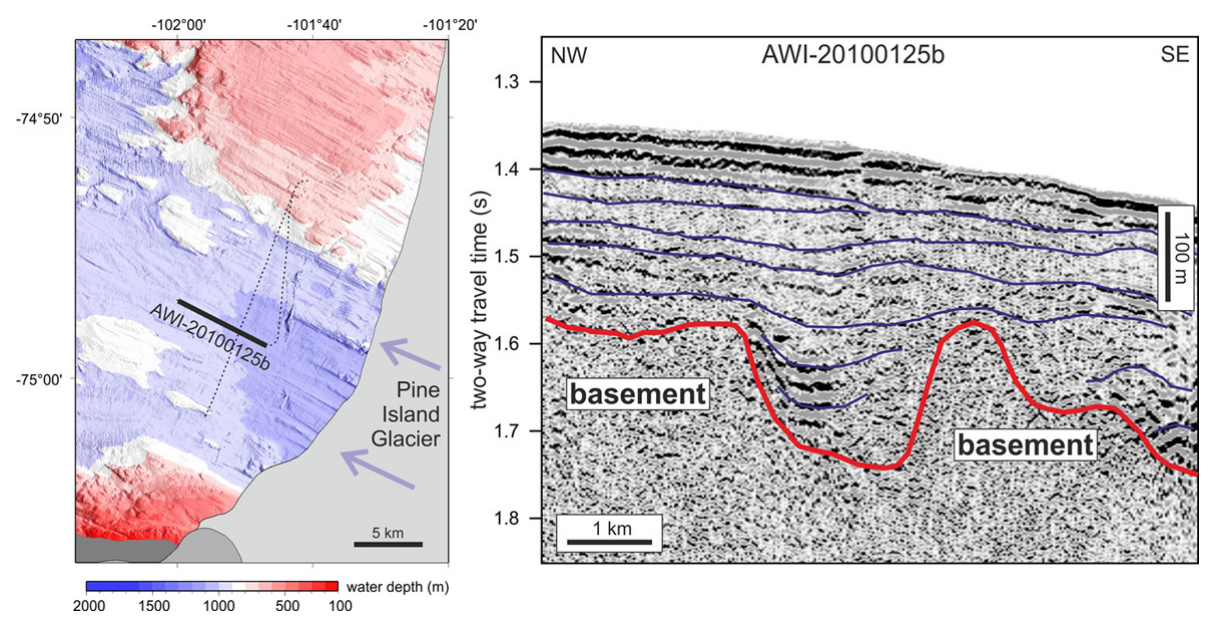

Fig. 6. Seismic profile (bold solid line) recording a sedimentary basin of at least $300 \mathrm{~m}$ thickness off the ice shelf edge of Pine Island Glacier. Dotted lines mark other seismic profiles. Blue lines in seismic section mark a set of horizons within the sedimentary strata. The vertical scale bar is based on an estimated seismic velocity of $2000 \mathrm{~m} \mathrm{~s}^{-1}$ in the sediments. See Fig. 2 for location.

crystalline bedrock and observed that the onset of ice streaming coincided with the transition to sedimentary substrate which dominates in zone 2.

Area 1 of this paper basically coincides with zone 2 of Lowe and Anderson (2002), while the new bathymetry compilation reveals a distinct change in seafloor morphology near the present ice shelf, allowing us to subdivide their zone 1 into areas 2 and 3 . Area 3 is less rugged and the shape of several features indicates a depositional origin rather than bedrock erosion (Figs. 2, 3). The absence of deep basins in this area suggests that they were either not excavated, e.g., due to different substrate properties or, if such basins were formed in the past, they have been filled with sediment as indicated by seismic data (Fig. 6), e.g., while the grounding line of the ice stream was located farther north. Smooth bottom morphology of some other deep basins in area 2 suggests they might be partly filled with sediment as well.

Lowe and Anderson $(2002,2003)$ argued that sedimentary substrate is largely absent south of the transition from sedimentary strata on the middle shelf to acoustic basement on the inner shelf at $\sim 73.5^{\circ} \mathrm{S}$. The only exception is a small patch of $\sim 100 \mathrm{~m}$ thick, layered sediments overlying acoustic basement on the up-stream flank of a crystalline bedrock outcrop that was recorded directly west of the Pine Island Glacier front by Kellogg and Kellogg (1987a). Lowe and Anderson (2003) assumed that these sediments are related to subglacial meltwater flow and form a seaward thinning wedge. Seismic profiling from R/V Polarstern in area 3 (Fig. 6) reveals $>300 \mathrm{~m}$ thick layered sedimentary strata extending over at least $10 \mathrm{~km}$, however. The nearhorizontal strata indicate basin-wide regular vertical deposition more indicative of basin fill than a wedge. Moreover, our multibeam data from this region clearly show subglacial lineations, which closely resemble sedimentary features of the mid- and outer shelf areas (Fig. 3e). This observation may imply that either the near-surface sediments are subglacial till or, if the assumption of Lowe and Anderson (2003) is correct, Pine Island Glacier overrode the subglacial meltwater sediments after their deposition. The lithology of core PS75/159-1 (Fig. 2) does not confirm the presence of till or meltwater deposits, but it does document the presence of unconsolidated sediments near the seabed (Gohl, 2010).

Based on observations of present ice flow and models of shear stress, Joughin et al. (2009) concluded that the main trunk of the modern Pine Island Glacier is resting on a mixed bed of soft sedimentary strata alternating with a hard substrate, possibly consisting of crystalline bedrock. This conclusion was recently supported by analyses of bed roughness under Pine Island Glacier and its tributaries (Rippin et al., 2011). The presence of crystalline bedrock and sedimentary beds in inner Pine Island Bay demonstrates that such a mixed bed also existed there. The sedimentary substrate possibly enabled or facilitated fast ice flow (e.g., Studinger et al., 2001). This finding implies that bed conditions and resulting flow of the paleo-Pine Island Ice Stream varied much more spatially than previously thought.

The general scarcity of sediment cover in areas 1 and 2 also suggests rapid post-LGM grounding-line retreat from the middle to inner shelf, assuming that subglacial sediment transport rates were as high as envisaged (e.g., Alley et al., 1989; Nygård et al., 2007). Although several shoals cross these areas, there is no geomorphological indication of a prolonged still stand of the grounding line, which would have resulted in the formation of a sedimentary ridge or grounding zone wedge as observed farther north in the Pine Island Trough (e.g., Lowe and Anderson, 2002; Graham et al., 2010; Jenkins et al., 2010; Jakobsson et al., 2011, 2012). Rapid deglaciation is also consistent with the radiocarbon chronology of sediment cores that indicates fast groundingline retreat from a grounding zone wedge north of the study 


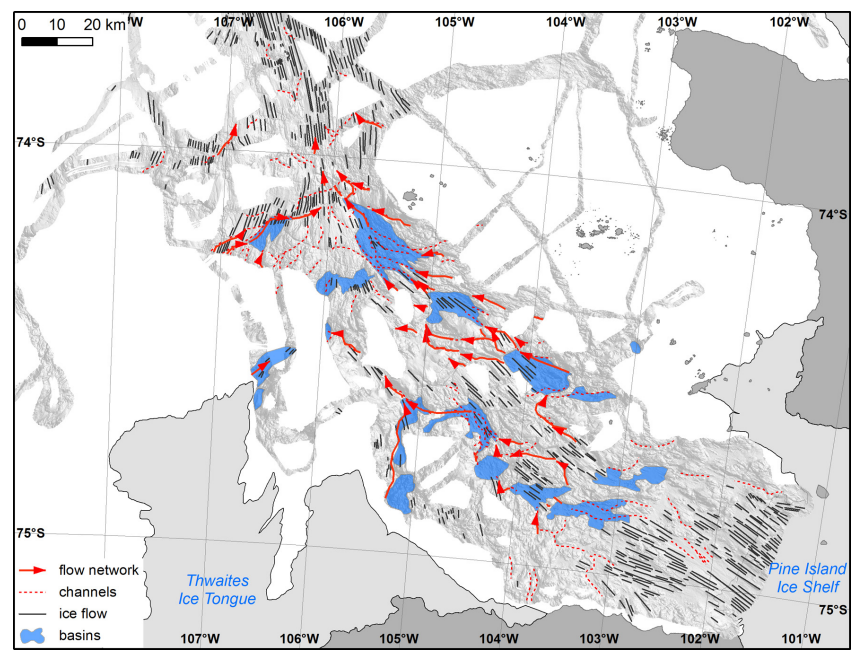

Fig. 7. Digitised lineations indicating ice flow (black), minor (dotted red) and major meltwater channels (red with arrows). The extent of swath bathymetry data is shown as grey shaded area. Light and dark grey shaded areas represent ice shelves and land, respectively, from the Antarctic Digital Database v6 (http://www.add.scar.org/). Note that smaller channels are cutting into the bottom of some larger basins.

area at $\sim 12$ cal kyr (Kirshner et al., 2012) and from inner Pine Island Bay before $\sim 10.3-11.7$ cal kyr (Hillenbrand et al., 2013).

While there is evidence that grounded ice retreated rapidly from the mid-shelf to the inner shelf and probably reached within $93 \mathrm{~km}$ of its current position as early as $\sim 11 \mathrm{kyr}$ ago (Hillenbrand et al., 2013), retreat might have been slower across area 3 , allowing sediments to be deposited in inner Pine Island Bay. This could have been a result of iceshelf buttressing caused by local pinning of grounded ice on islands and peninsulas surrounding inner Pine Island Bay. Modern observations indicate that the grounding line of Pine Island Glacier has retreated by $\sim 30 \mathrm{~km}$ since 1973 (Jenkins et al., 2010), with $\sim 20 \mathrm{~km}$ of this retreat occurring rapidly from 1992 to 2007 (Rignot, 1998; Shepherd et al., 2001; Jenkins et al., 2010). A stable grounding line deep within inner Pine Island Bay, caused by buttressing from the surrounding land (Fig. 1) or pinning on the shallower ridges in this area for much of the Holocene, could have provided a source for the observed sediments in this area. In addition, some of the sediments of $300 \mathrm{~m}$ thick sequence could have been deposited during previous glaciations and escaped excavation during the last glacial period. Determining the origin and age of these sediments will require longer sediment cores than can be recovered with standard gravity and piston coring.

\subsection{Meltwater flow}

Studies that first reported some of the seafloor basins and channels in Pine Island Bay interpreted them as meltwater features (Lowe and Anderson, 2002, 2003). The more detailed mapping of these basins and channels allows reconstruction of the associated flow network (Fig. 7). The undulating character of many channels and their deep incision into bedrock strongly suggests subglacial formation, and the extensive network of channels and basins indicates the former presence of abundant subglacial meltwater. In general, low basal shear stress over sedimentary substrate facilitates fast ice flow, whereas high basal shear stress over hard, rugged bedrock results in slow flow (Bell et al., 1998; Wellner et al., 2001). However, abundant subglacial meltwater in innermost Pine Island Bay could have lubricated the paleo-ice stream bed, allowing fast ice flow across stretches of rugged bedrock topography if the volume of meltwater was sufficient to flow both within major channels and across non-channelised areas (cf. Kamb, 2001; Bell, 2008). If meltwater flow was restricted to a channel system, then basal shear stresses are likely to have been higher, with the possibility that rugged bedrock perturbations acted as localised sticky spots.

Basins and channels are most abundant in area 2. No large channels are present in area 3 and north of area 1, although there are a few smaller ones (Fig. 3e). Subglacial meltwater channels with dimensions greater than the spatial resolution of multibeam swath bathymetry systems have been observed in sedimentary substrate underlying modern Antarctic ice streams (e.g., King et al., 2004). Large channels have also been reported near the mouth of the Belgica Trough (Noormets et al., 2009) and on the mid-shelf in the Ross Sea (Wellner et al., 2006), but overall there is a lack of such features in sediments covering the mid- and outer shelf sections of all known Antarctic paleo-ice stream troughs (Ó Cofaigh et al., 2005). One mechanism to explain their absence is that water could be transported through the sediment, i.e., by Darcian flow within the subglacial till, which has a higher permeability than the acoustic basement (Kamb, 2001). Although low till permeability might not be sufficient to transport large amounts of water quickly, microscopic studies on tills from Antarctic paleo-ice stream troughs have revealed ductile deformation structures in soft till overlying dewatered stiff till (Reinardy et al., 2011). This observation suggests significant basal meltwater transfer within the subglacial sediment bed. The water could also be distributed and transported in a broad, thin layer at the ice-sediment interface (Walder and Fowler, 1994; Noormets et al., 2009), which is apparently occurring at the bed of some modern ice streams (e.g., Peters et al., 2007). In these cases, constant reworking of sediment could prevent the establishment of a permanent channel system. Since overriding grounded ice probably overprinted previously formed sedimentary features on the Antarctic continental shelf throughout the last glacial period, the subglacial sedimentary bedforms observed today in soft substrate areas 
are likely to be only the last snapshot of basal conditions just before the grounded ice retreated (e.g., Smith et al., 2007; King et al., 2009). For smaller meltwater volumes, transport in the sediment layer is the most likely scenario, while we would expect larger, episodic floods to create meltwater channels in sediments underneath grounded ice. If such floods happened earlier during the last glacial period or during previous glaciations, their deposits could have been reworked by grounded ice during the last ice stream advance.

\subsection{Potential sources of meltwater}

Although we can measure the size of the basins and channels, it is unclear when, to what extent and how long they contained meltwater. It is unlikely that all large basins were completely filled with meltwater. Instead, the basins were probably partially filled with meltwater at the bottom and ice above. And even if different basins harboured meltwater at different times, a significant amount of sub-glacial meltwater would have been required to form such an extensive channel network.

The most common source of subglacial water is melting at the bottom of the ice sheet due to a combination of ice thickness, geothermal heat flux at the bed, and frictional heating due to rapid ice flow (Joughin et al., 2004; Llubes et al., 2006). Meltwater production could be enhanced by a higher geothermal gradient underneath parts of the WAIS (Shapiro and Ritzwoller, 2004). Joughin et al. (2009) modelled a basal melt rate of $1.7 \mathrm{~km}^{3} \mathrm{yr}^{-1}$ for the present day Pine Island Glacier system, which is significantly higher than previous, conservative estimates of $0.24-0.5 \mathrm{~km}^{3} \mathrm{yr}^{-1}$ by Lowe and Anderson (2003). If the water flowed continuously through the $0.49 \mathrm{~km}^{2}$ cross-section of one of the major channels (Fig. 3g), it would trickle along at $0.1 \mathrm{~mm} \mathrm{~s}^{-1}$, and increase only to a few $\mathrm{mm} \mathrm{s}^{-1}$ if the channel was mostly filled by ice. Although sufficient to transport the meltwater generated by pressure melting, it seems unlikely that such low flow rates could erode the observed channel network.

Joughin et al. (2009) calculated a higher melt rate of $3.5 \mathrm{~km}^{3} \mathrm{yr}^{-1}$ for the current Thwaites Glacier. If the potential meltwater production of the Thwaites Glacier was also larger than that of Pine Island Glacier in the past, we would expect a major contribution from the Thwaites system to the meltwater network in Pine Island Bay. Indeed, the bathymetry shows several large channels originating from the grounding line of Thwaites Glacier, indicating meltwater contribution from this system. The channel network also indicates that meltwater entered the paleo-ice stream trough from the Velasco Glacier and northern Hudson Mountains northeast of the main trough (Figs. 2, 7), where no large ice stream is currently located. There, thicker ice and a modified ice flow pattern during periods of maximum glaciation could have created basal conditions that also favoured subglacial melting.

An alternative or additional source of meltwater could be related to subglacial volcanic activity. The hinterland of the
Amundsen Sea contains numerous volcanoes including the Hudson Mountains just east of Pine Island Bay (LeMasurier, 1990). Studies have shown that volcanoes, in the Marie Byrd Land volcanic province were active during the Pleistocene when this area was covered with an ice sheet (Blankenship et al., 1993; Wilch et al., 1999). An unusual reflector in radar data suggests a volcanic eruption in the Hudson Mountains as recently as $2200 \mathrm{yr}$ ago (Corr and Vaughan, 2008). A volcanic eruption has the potential to produce large amounts of meltwater and, thus, could trigger a large flood event (Roberts, 2005; Bennett et al., 2009). If it covered a large area with volcanic ash that reduced albedo and facilitated surface melting, water might penetrate through the glacier to its bed and form highly erosive moulins as in Greenland today (Eyles, 2006; Sundal et al., 2011).

Overall, it seems likely that meltwater erosion of these large basins and channels occurred episodically over many glacial cycles. The question remains as to when these basins and channels formed and when they were last subject to subglacial water storage and drainage.

\subsection{Timing of meltwater flow and channel development}

The deep ( $>300 \mathrm{~m}$ ) incisions of the large channels and the formation of the deep bedrock basins suggest that these features formed as a result of many flow events over the period of many glacial cycles, possibly since the Mid-Miocene (Lowe and Anderson, 2003). Although we do not know the precise nature of the bedrock, the lack of visible reflections in available seismic data suggests that these are not sedimentary, but rather igneous or metamorphic rocks, which are less erodible and were reported from several outcrops in the Pine Island Bay region (e.g., Debese et al., 2012; Sheen et al., 2012).

The development of similar channels and basins over many glacial cycles has also been suggested for the neighbouring Getz and Dotson areas (Graham et al., 2009; Smith et al., 2009b) and Marguerite Bay (Anderson and Fretwell, 2008). A larger number of smaller channels and basins may have been active during early glaciations, with some capturing more of the ice and meltwater flow over time and, as a result, have become larger, capturing more and more of the subglacial meltwater flow. In addition to meltwater flow, formation of the larger basins could have been initiated by overdeepening processes that are often observed under glaciers (Cook and Swift, 2012).

So far no dates have been reported that would directly allow the identification and timing of different flow events. Based on thick coarse-grained layers found in a sediment core from a smaller channel (PC46; Fig. 2) Lowe and Anderson (2003) suggested that a major outburst flood occurred at the end of the last glaciation, since these units are not overlain by post LGM sediments. However, Smith et al. (2009b) concluded that similar layers recovered from subglacial meltwater channels in front of the Dotson-Getz ice shelves might 
have been re-deposited from the steep sides of the channels by gravitational down-slope processes. One of their studied cores recovered LGM till, but no sediments of possibly fluvial origin, giving evidence for channel formation before the last grounded ice advance.

As sediment core PC46 was taken from a smaller side channel (Fig. 2), that core may not be representative of the entire flow network. No sediment cores have been recovered from the main channels despite several attempts, but numerous cores successfully targeted the basin infills of area 2 . Some of these basins contain several $10 \mathrm{~s}$ of metres of sediment and the up to $10 \mathrm{~m}$-long cores recovered unconsolidated fine-grained glacimarine sediments of probable Holocene age (Ehrmann et al., 2011), but no thick units of coarsegrained fluvial sediments similar to those in core PC46 were found as would have been expected from meltwater flow deposits at the LGM or during the last deglaciation. We cannot rule out the possibility that LGM meltwater flow deposits are present within the basins at larger sub-bottom depth, i.e., beyond the reach of standard gravity and piston coring. However, the recovery of a basal diamicton possibly representing a subglacial till at site PS69/295-1 (Ehrmann et al., 2011), combined with the lack of sediment indicating recently active channel-basin networks (Figs. 4, 5), suggests that such flows were mainly active during pre-LGM times and that grounded ice-sheet advance during more recent glacial periods eroded the coarse material and transported it offshore.

Kirshner et al. (2012) argued that a widespread draping silt unit within Pine Island Bay (Unit 1) may have been sourced by plumes of sediment-laden water flowing from beneath the Pine Island ice stream based on its unique character (well sorted silt with virtually no ice-rafted debris [IRD] or microfossils) and the rapid and dramatic change from more proximal glacimarine sedimentation to this style of sedimentation at $\sim 7000$ cal yr BP.

\subsection{Comparison with other Antarctic meltwater networks}

The subglacial meltwater features in Pine Island Bay are not unique. Similar features have been observed in other parts of the inner Antarctic continental shelf (Wellner et al., 2006) including Marguerite Bay (Ó Cofaigh et al., 2002, 2005; Anderson and Fretwell, 2008), the Dotson-Getz Trough (Larter et al., 2009; Smith et al., 2009b), and the western Antarctic Peninsula (Evans et al., 2004; Domack et al., 2006). In addition, similar terrestrial meltwater features discovered in the Transantarctic Mountains have been interpreted to have formed between 12.2 and $14.4 \mathrm{Myr}$ ago through erosion by fast-flowing subglacial meltwater during multiple flow events (Sugden and Denton, 2004; Lewis et al., 2006).

There is increasing evidence for active subglacial lakes below the Antarctic ice sheets (Bell et al., 2007; Fricker et al., 2007; Smith et al., 2009a). Satellite altimetry data show changes in surface elevations that indicate draining of some lakes and refilling of others (Wingham et al., 2006; Fricker et al., 2007). Fricker and Scambos (2009) identified a series of $20-30 \mathrm{~km}$-wide subglacial lakes close to the grounding line of Mercer and Whillans ice streams (Siple Coast, West Antarctica). These dimensions are of the same order as the large basins described in this paper, although the bedrock geology might be different. Similar to the proposed mechanisms described by Fricker and Scambos (2009), subglacial meltwater draining into inner Pine Island Bay could have collected in one basin until a water pressure threshold was reached. When water pressure lifted the ice barrier in the connecting channels, the water drained into the next basin downstream. More generally, the observed bedrock structures in Pine Island Bay seem likely to channelise meltwater flow between basins at the expense of sheet flow at the ice-bed interface.

Details on scales up to a few hundred metres are usually not resolved in radar data. High-resolution swath bathymetry data capable of resolving such features on the continental shelves of formerly glaciated margins can, thus, provide valuable information about subglacial meltwater flow and help to understand drainage processes at the base of contemporary ice sheets.

\section{Conclusions}

This compilation of old and new swath bathymetry data from Pine Island Bay provides a coherent and detailed picture of a formerly glaciated inner continental shelf allowing more complete mapping and analysis of bedforms than previously available from discrete swath tracks. The resulting map reveals details that are critical for the understanding of past ice flow behaviour, subglacial processes and their spatial variability.

Our compilation confirms and extends the general zonation of erosional subglacial bedforms in crystalline bedrock on the inner shelf and subglacial depositional features on sedimentary substrate on the mid-shelf as previously identified by Lowe and Anderson (2002). Added here is a zone nearest the Pine Island Ice Shelf front characterised by smooth topography and showing up to $300 \mathrm{~m}$ of sediments. This finding documents that sedimentary substrate on the inner shelf of Pine Island Bay is more widespread than previously thought. The complex pattern of rugged crystalline basement alternating with smooth sedimentary substrate in inner Pine Island Bay is consistent with observations under the modern Pine Island Glacier. The seafloor topography and sediment presence of inner Pine Island Bay indicate that post-LGM floating and partially grounded ice may have persisted in the area directly in front of the modern ice front for a longer time than in other parts of the Pine Island Trough system.

The orientation and location of the complex subglacial meltwater channel network suggest significant meltwater supply not only from Pine Island Glacier, but also from the 
Thwaites Glacier and from the Hudson Mountains. Meltwater volumes currently generated underneath the Pine Island and Thwaites glaciers would probably not be sufficient to generate the observed channel-basin network if discharged continuously. More likely this network was generated over several glacial cycles by episodic flow events caused by storage and release of meltwater through subglacial lakes, with possible additional contributions from subglacial volcanic eruptions.

Comparison of basin dimensions with those of modern subglacial lakes suggests that the active systems might be connected by channel networks resembling those in Pine Island Bay. The increasing number of paleo-meltwater features discovered by high-resolution swath bathymetry on different parts of the Antarctic continental margin provides a detailed, view of subglacial flow systems that should allow further consideration of related hydrodynamic processes and ice dynamics. A better understanding of the timing and nature of subglacial meltwater flow in Pine Island Bay will require more targeted sediment sampling from the large basins and channels, some beyond the range of standard piston coring, and improved sub-bottom or high-resolution seismic coverage of these features.

Acknowledgements. We thank the masters and crews of the research vessels, R/V Nathaniel B. Palmer, RRS James Clark Ross, IB Oden and R/V Polarstern for their support during the data acquisition. Numerous people were directly involved in processing and editing the data. Nick Rackebrandt (University of Bremen) provided the map with estimated sediment thickness in Pine Island Bay. F. Nitsche was supported by NSF grants ANT 08-38735 and ANT 06-32282, S. Jacobs by NSF grant ANT 06-32282 and J. Anderson by NSF/ARRA grant ANT-0837925. The IB Oden expedition OSO0708 was carried out as collaboration between Swedish Polar Research Secretariat, the Swedish Research Council and the US National Science Foundation (NSF).

Edited by: C. R. Stokes

\section{References}

Alley, R. B., Blankenship, D., Rooney, S. T., and Bentley, C. R.: Sedimentation beneath ice shelves - the view from Ice Stream B, Mar. Geol., 85, 101-120, 1989.

Anderson, J. B. and Fretwell, L. O.: Geomorphology of the onset area of a paleo-ice stream, Marguerite Bay, Antarctic Peninsula, Earth Surf. Processes, 33, 503-512, 2008.

Anderson, J. B., Shipp, S. S., Lowe, A. L., Wellner, J. S., and Mosola, A. B.: The Antarctic Ice Sheet during the Last Glacial Maximum and its subsequent retreat history: a review, Quaternary Sci. Rev., 21, 49-70, 2002.

Bell, R. E., Blankenship, D. D., Finn, C. A., Morse, D. L., Scambos, T. A., Brozena, J. M., and Hodge, S. M.: Influence of subglacial geology on the onset of a West Antarctic ice stream from aerogeophysical observations, Nature, 394, 58-62, 1998.
Bell, R. E., Studinger, M., Shuman, C. A., Fahnestock, M. A., and Joughin, I.: Large subglacial lakes in East Antarctica at the onset of fast-flowing ice streams, Nature, 445, 904-907, 2007.

Bell, R. E.: The role of subglacial water in ice-sheet mass balance, Nature Geosci., 1, 297-304, 2008.

Bennett, M. R.: Ice streams as the arteries of an ice sheet: their mechanics, stability and significance, Earth-Sci. Rev., 61, 309339, 2003.

Bennett, M. R. and Glasser, N. F.: Glacial geology: ice sheets and landforms, John Wiley and Sons Ltd, Chichester, UK, 364 pp., 1996.

Bennett, M. R., Huddart, D., and Gonzalez, S.: Glaciovolcanic landsystems and large-scale glaciotectonic deformation along the Brekknafjöll-Jarlhettur, Iceland, Quaternary Sci. Rev., 28, 647676, 2009.

Bentley, C. R.: Antarctic ice streams: A review, J. Geophys. Res., 92, 8843-8858, 1987.

Blankenship, D. D., Bell, R. E., Hodge, S. M., Brozena, J. M., Behrendt, J. C., and Finn, C. A.: Active volcanism beneath the West Antarctic ice sheet and implications for ice-sheet stability, Nature, 361, 526-529, 1993.

Booth, D. B. and Hallet, B.: Channel networks carved by subglacial water: Observations and reconstruction in the eastern Puget Lowland of Washington, Geol. Soc. Am. Bull., 105, 671-683, 1993.

Boulton, G. S. and Clark, C. D.: A highly mobile Laurentide ice sheet revealed by satellite images of glacial lineations, Nature, 346, 813-817, 1990.

Canals, M., Urgeles, R., and Calafat, A. M.: Deep sea-floor evidence of past ice streams off the Antarctic Peninsula, Geology, 28, 3134, 2000.

Caress, D. W. and Chayes, D. N.: Improved processing of Hydrosweep DS multibeam data on the R/V Maurice Ewing, Mar. Geophys. Res., 18, 631-650, 1996.

Clark, C. D.: Mega-scale glacial lineations and cross-cutting iceflow landforms, Earth Surf. Processes, 18, 1-29, 1993.

Cook, S. J. and Swift, D. A.: Subglacial basins: Their origin and importance in glacial systems and landscapes, Earth-Sci. Rev., 115, 332-372, doi:10.1016/j.earscirev.2012.09.009, 2012.

Corr, H. F. J. and Vaughan, D. G.: A recent volcanic eruption beneath the West Antarctic ice sheet, Nature Geosci., 1, 122-125, 2008.

Debese, N., Moitié, R., and Seube, N.: Multibeam echosounder data cleaning through a hierarchic adaptive and robust local surfacing, Comp. Geosci., 46, 330-339, doi:10.1016/j.cageo.2012.01.012, 2012.

Domack, E., Amblàs, D., Gilbert, R., Brachfeld, S., Camerlenghi, A., Rebesco, M., Canals, M., and Urgeles, R.: Subglacial morphology and glacial evolution of the Palmer deep outlet system, Antarctic Peninsula, Geomorphology, 75, 125-142, 2006.

Dowdeswell, J. A., Ottesen, D., Rise, L., and Craig, J.: Identification and preservation of landforms diagnostic of past ice-sheet activity on continental shelves from three-dimensional seismic evidence, Geology, 35, 359-362, 2007.

Drewry, D. J., Jordan, S. R., and Jankowski, E.: Measured properties of the Antarctic ice sheet: surface configuration, ice thickness, volume and bedrock characteristics, Ann. Glaciol., 3, 8391, 1982.

Ehrmann, W., Hillenbrand, C. D., Smith, J. A., Graham, A. G. C., Kuhn, G., and Larter, R. D.: Provenance changes between 
recent and glacial-time sediments in the Amundsen Sea embayment, West Antarctica: clay mineral assemblage evidence, Antarct. Sci., 1, 1-16, 2011.

Evans, J., Dowdeswell, J. A., and Ó Cofaigh, C.: Late Quaternary submarine bedforms and ice-sheet flow in Gerlache Strait and on the adjacent continental shelf, Antarctic Peninsula, J. Quaternary Sci., 19, 397-407, 2004.

Eyles, N.: The role of meltwater in glacial processes, Sediment. Geol., 190, 257-268, 2006.

Fricker, H. A. and Scambos, T. A.: Connected subglacial lake activity on lower Mercer and Whillans Ice Streams, West Antarctica, 20032008, J. Glaciol., 55, 303-315, doi:10.3189/002214309788608813, 2009.

Fricker, H. A., Scambos, T., Bindschadler, R., and Padman, L.: An Active Subglacial Water System in West Antarctica Mapped from Space, Science, 315, 1544-1548, doi:10.1126/science.1136897, 2007.

Gohl, K.: The Expedition of the Research Vessel "Polarstern" to the Amundsen Sea, Antarctica, in 2010 (ANT-XXVI/3), Berichte zur Polar- und Meeresforschung, Alfred Wegener Institute for Polar and Marine Research, Bremerhaven, Germany, 168 pp., 2010.

Graham, A. G. C., Larter, R. D., Gohl, K., Hillenbrand, C.-D., Smith, J. A., and Kuhn, G.: Bedform signature of a West Antarctic palaeo-ice stream reveals a multi-temporal record of flow and substrate control, Quaternary Sci. Rev., 28, 2774-2793, 2009.

Graham, A. G. C., Larter, R. D., Gohl, K., Dowdeswell, J. A., Hillenbrand, C.-D., Smith, J. A., Evans, J., Kuhn, G., and Deen, T.: Flow and retreat of the Late Quaternary Pine IslandThwaites palaeo-ice stream, West Antarctica, J. Geophys. Res., 115, F03025, doi:10.1029/2009jf001482, 2010.

Grant, J. A. and Schreiber, R.: Modern swath sounding and subbottom profiling technology for research applications: The Atlas Hydrosweep and Parasound Systems, Mar. Geophys. Res., 12, 9-19, doi:10.1007/bf00310559, 1990.

Hellmer, H. H., Jacobs, S. S., and Jenkins, A.: Oceanic Erosion of a Floating Antarctic Glacier in the Amundsen Sea, Antarct. Res. Ser., 75, 83-99, 1998.

Hillenbrand, C.-D., Kuhn, G., Smith, J. A., Gohl, K., Graham, A. G. C., Larter, R. D., Klages, J. P., Downey, R., Moreton, S. G., Forwick, M., and Vaughan, D. G.: Grounding-line retreat of the West Antarctic Ice Sheet from inner Pine Island Bay, Geology, 41, 35-38, doi:10.1130/G33469.1, 2013.

Hughes, T.: Is West Antarctic Ice-Sheet Disintegrating?, J. Geophys. Res., 78, 7884-7910, 1973.

IPCC: Climate Change 2007: The Physical Science Basis, Contribution of Working Group I to the Fourth Assessment Report of the Intergovernmental Panel on Climate Change, edited by: Solomon, S., Qin, D., Manning, M., Chen, Z., Marquis, M., Averyt, K. B., Tignor, M., and Miller, H. L., Cambridge University Press, Cambridge, UK, and New York, NY, USA, 996 pp., 2007.

Jacobs, S. S., Hellmer, H. H., and Jenkins, A.: Antarctic ice sheet melting in the Southeast Pacific, Geophys. Res. Lett., 23, 957960, 1996

Jacobs, S. S., Jenkins, A., Giulivi, C. F., and Dutrieux, P.: Stronger ocean circulation and increased melting under Pine Island Glacier ice shelf, Nature Geosci., 4, 519-523, doi:10.1038/ngeo1188, 2011

Jakobsson, M., Anderson, J. B., Nitsche, F. O., Dowdeswell, J. A., Gyllencreutz, R., Kirchner, N., Mohammad, R., O'Regan, M.,
Alley, R. B., Anandakrishnan, S., Eriksson, B., Kirshner, A., Fernandez, R., Stolldorf, T., Minzoni, R., and Majewski, W.: Geological record of ice shelf break-up and grounding line retreat, Pine Island Bay, West Antarctica, Geology, 39, 691-694, doi:10.1130/g32153.1, 2011.

Jakobsson, M., Anderson, J. B., Nitsche, F. O., Gyllencreutz, R., Kirshner, A. E., Kirchner, N., O'Regan, M., Mohammad, R., and Eriksson, B.: Ice sheet retreat dynamics inferred from glacial morphology of the central Pine Island Bay Trough, West Antarctica, Quaternary Sci. Rev., 38, 1-10, doi:10.1016/j.quascirev.2011.12.017, 2012.

Jenkins, A., Vaughan, D. G., Jacobs, S. S., Hellmer, H. H., and Keys, J. R.: Glaciological and oceanographic evidence of high melt rates beneath Pine island glacier, west Antarctica, J. Glaciol., 43, 114-121, 1997.

Jenkins, A., Dutrieux, P., Jacobs, S. S., McPhail, S. D., Perrett, J. R., Webb, A. T., and White, D.: Observations beneath Pine Island Glacier in West Antarctica and implications for its retreat, Nature Geosci., 3, 468-472, 2010.

Johnson, J. S., Bentley, M. J., and Gohl, K.: First exposure ages from the Amundsen Sea Embayment, West Antarctica: The Late Quaternary context for recent thinning of Pine Island, Smith, and Pope Glaciers, Geology, 36, 223-226, 2008.

Jorgensen, F. and Sandersen, P. B. E.: Buried and open tunnel valleys in Denmark-erosion beneath multiple ice sheets, Quaternary Sci. Rev., 25, 1339-1363, 2006.

Joughin, I. and Alley, R. B.: Stability of the West Antarctic ice sheet in a warming world, Nature Geosci., 4, 506-513, 2011.

Joughin, I., Tulaczyk, S., MacAyeal, D. R., and Engelhardt, H.: Melting and freezing beneath the Ross ice streams, Antarctica, J. Glaciol., 50, 96-108, doi:10.3189/172756504781830295, 2004.

Joughin, I., Tulaczyk, S., Bamber, J. L., Blankenship, D., Holt, J. W., Scambos, T., and Vaughan, D. G.: Basal conditions for Pine Island and Thwaites Glaciers, West Antarctica, determined using satellite and airborne data, J. Glaciol., 55, 245-257, 2009.

Joughin, I., Smith, B. E., and Holland, D. M.: Sensitivity of 21 st century sea level to ocean-induced thinning of Pine Island Glacier, Antarctica, Geophys. Res. Lett, 37, L20502, doi:10.1029/2010GL044819, 2010.

Kamb, B.: Basal zone of the West Antarctic ice streams and its role in lubrication of their rapid motion, in: The West Antarctic Ice Sheet: Behavior and Environment, Antarct. Res. Ser., 77, edited by: Alley, R. B. and Bindschadler, R. A., 0066-4634, American Geophysical Union, Washington, DC, USA, 157-199, 2001.

Kellogg, T. B. and Kellogg, D. E.: Late Quaternary deglaciation of the Amundsen Sea: implications for ice sheet modelling, in: The Physical Basis of Ice Sheet Modelling, Proceedings of the Vancouver Symposium, edited by: Waddington, E. D. and Walder, J. S., IAHS Publication, Vancouver, Canada, 349-357, 1987a.

Kellogg, T. B. and Kellogg, D. E.: Recent glacial history and rapid ice stream retreat in the Amundsen Sea, J. Geophys. Res., 92, 8859-8864 1987b.

King, E. C., Woodward, J., and Smith, A. M.: Seismic evidence for a water-filled canal in deforming till beneath Rutford Ice Stream, West Antarctica, Geophys. Res. Lett., 31, L20401, doi:10.1029/2004GL020379, 2004.

King, E. C., Hindmarsh, R. C. A., and Stokes, C. R.: Formation of mega-scale glacial lineations observed beneath a West Antarctic ice stream, Nature Geosci., 2, 585-588, 2009. 
Kirshner, A. E., Anderson, J. B., Jakobsson, M., O'Regan, M., Majewski, W., and Nitsche, F. O.: Post-LGM deglaciation in Pine Island Bay, West Antarctica, Quaternary Sci. Rev., 38, 11-26, doi:10.1016/j.quascirev.2012.01.017, 2012.

Larter, R. D., Graham, A. G. C., Gohl, K., Kuhn, G., Hillenbrand, C.-D., Smith, J. A., Deen, T. J., Livermore, R. A., and Schenke, H.-W.: Subglacial bedforms reveal complex basal regime in a zone of paleo-ice stream convergence, Amundsen Sea embayment, West Antarctica, Geology, 37, 411-414, doi:10.1130/g25505a.1, 2009.

LeMasurier, W. E.: Late Cenozoic Volcanism on the Antarctic Plate: An Overview, in: Volcanoes of the Antarctic Plate and Southern Oceans, edited by: LeMasurier, W. E. and Thomson, J. W., Antarctic Research Series, Vol. 48, American Geophysical Union, Washington, DC, USA, 1-17, 1990.

Lewis, A. R., Marchant, D. R., Kowalewski, D. E., Baldwin, S. L., and Webb, L. E.: The age and origin of the Labyrinth, western Dry Valleys, Antarctica: Evidence for extensive middle Miocene subglacial floods and freshwater discharge to the Southern Ocean, Geology, 34, 513-516, doi:10.1130/g22145.1, 2006.

Livingstone, S. J., Ó Cofaigh, C., Stokes, C. R., Hillenbrand, C. D., Vieli, A., and Jamieson, S. S. R.: Antarctic palaeo-ice streams, Earth-Sci. Rev., 111, 90-128, 2012.

Llubes, M., Lanseau, C., and Rémy, F.: Relations between basal condition, subglacial hydrological networks and geothermal flux in Antarctica, Earth Planet. Sci. Lett., 241, 655-662, doi:10.1016/j.epsl.2005.10.040, 2006.

Lowe, A. L. and Anderson, J. B.: Reconstruction of the West Antarctic Ice Sheet in Pine Island Bay during the Last Glacial Maximum and its subsequent retreat history, Quaternary Sci. Rev., 21, 1879-1897, 2002.

Lowe, A. L. and Anderson, J. B.: Evidence for abundant subglacial meltwater beneath the paleo-ice sheet in Pine Island Bay, Antarctica, J. Glaciol., 49, 125-138, 2003.

Nitsche, F. O., Jacobs, S., Larter, R. D., and Gohl, K.: Bathymetry of the Amundsen Sea Continental Shelf: Implications for Geology, Oceanography, and Glaciology, Geochem. Geophys. Geosyst., 8, Q10009, doi:10.1029/2007GC001694, 2007.

Noormets, R., Dowdeswell, J. A., Larter, R. D., Ó Cofaigh, C., and Evans, J.: Morphology of the upper continental slope in the Bellingshausen and Amundsen Seas - Implications for sedimentary processes at the shelf edge of West Antarctica, Mar. Geol., 258, 100-114, 2009.

Nygård, A., Sejrup, H. P., Haflidason, H., Lekens, W. A. H., Clark, C. D., and Bigg, G. R.: Extreme sediment and ice discharge from marine-based ice streams: New evidence from the North Sea, Geology, 35, 395-398, doi:10.1130/g23364a.1, 2007.

Ó Cofaigh, C., Pudsey, C. J., Dowdeswell, J., and Morris, P.: Evolution of subglacial bedforms along a paleo-ice stream, Antarctic Peninsula continental shelf, Geophys. Res. Lett., 29, 1199, doi:10.1029/2001GL014488, 2002.

Ó Cofaigh, C., Dowdeswell, J. A., Allen, C. S., Hiemstra, J. F., Pudsey, C. J., Evans, J., and J.A. Evans, D.: Flow dynamics and till genesis associated with a marine-based Antarctic palaeo-ice stream, Quaternary Sci. Rev., 24, 709-740, 2005.

Peters, L. E., Anandakrishnan, S., Alley, R. B., and Smith, A. M.: Extensive storage of basal meltwater in the onset region of a major West Antarctic ice stream, Geology, 35, 251-254, doi:10.1130/g23222a.1, 2007.
Pritchard, H. D., Arthern, R. J., Vaughan, D. G., and Edwards, L. A.: Extensive dynamic thinning on the margins of the Greenland and Antarctic ice sheets, Nature, 461, 971-975, 2009.

Pritchard, H. D., Ligtenberg, S. R. M., Fricker, H. A., Vaughan, D. G., van den Broeke, M. R., and Padman, L.: Antarctic ice-sheet loss driven by basal melting of ice shelves, Nature, 484, 502-505, doi:10.1038/nature10968, 2012.

Rackebrandt, N.: Mapping of the PARASOUND penetration depth in the Pine Island Bay, West Antarctica, Term Paper, Master of Science Marine Geosciences, Department of Geosciences, University of Bremen, Germany, 22 pp., 2006.

Reinardy, B. T. I., Hiemstra, J. F., Murray, T., Hillenbrand, C.-D., and Larter, R. D.: Till genesis at the bed of an Antarctic Peninsula palaeo-ice stream as indicated by micromorphological analysis, Boreas, 40, 498-517, doi:10.1111/j.1502-3885.2010.00199, 2011.

Rignot, E. and Jacobs, S. S.: Rapid Bottom Melting Widespread near Antarctic Ice Sheet Grounding Lines, Science, 296, 20202023, doi:10.1126/science.1070942, 2002.

Rignot, E. and Thomas, R. H.: Mass balance of polar ice sheets, Science, 297, 1502-1506, 2002.

Rignot, E. J.: Fast recession of a West Antarctic glacier, Science, 281, 549-551, 1998.

Rignot, E., Bamber, J. L., van den Broeke, M. R., Davis, C., Li, Y., van de Berg, W. J., and van Meijgaard, E.: Recent Antarctic ice mass loss from radar interferometry and regional climate modelling, Nature Geosci., 1, 106-110, 2008.

Rignot, E., Velicogna, I., van den Broeke, M. R., Monaghan, A., and Lenaerts, J.: Acceleration of the contribution of the Greenland and Antarctic ice sheets to sea level rise, Geophys. Res. Lett., 38, L05503, doi:10.1029/2011g1046583, 2011.

Rippin, D. M., Vaughan, D. G., and Corr, H. F. J.: The basal roughness of Pine Island Glacier, West Antarctica, J. Glaciol., 57, 6776, doi:10.3189/002214311795306574, 2011.

Roberts, M. J.: Jökulhlaups: A reassessment of floodwater flow through glaciers, Rev. Geophys., 43, RG1002, doi:10.1029/2003rg000147, 2005.

Schoof, C.: Ice sheet grounding line dynamics: Steady states, stability, and hysteresis, J. Geophys. Res., 112, F03S28, doi:10.1029/2006JF000664, 2007.

Shapiro, N. M. and Ritzwoller, M. H.: Inferring surface heat flux distributions guided by a global seismic model: particular application to Antarctica, Earth Planet. Sci. Lett., 223, 213-224, doi:10.1016/j.eps1.2004.04.011, 2004.

Sheen, K. L., White, N. J., Caulfield, C. P., and Hobbs, R. W.: Seismic imaging of a large horizontal vortex at abyssal depths beneath the Sub-Antarctic Front, Nature Geosci., 5, 542-546, doi:10.1038/ngeo1502, 2012.

Shepherd, A. and Wingham, D.: Recent Sea-Level Contributions of the Antarctic and Greenland Ice Sheets, Science, 315, 15291532, doi:10.1126/science.1136776, 2007.

Shepherd, A., Wingham, D. J., Mansley, J. A. D., and Corr, H. F. J.: Inland thinning of Pine Island Glacier, West Antarctica, Science, 291 862-864, 2001.

Shepherd, A., Wingham, D., and Rignot, E.: Warm ocean is eroding West Antarctic Ice Sheet, Geophys. Res. Lett., 31, L23402, doi:10.1029/2004GL021106, 2004.

Smith, A. M., Murray, T., Nicholls, K. W., Makinson, K., Adjalgeirsdóttir, G., Behar, A. E., and Vaughan, D. G.: Rapid erosion, 
drumlin formation, and changing hydrology beneath an Antarctic ice stream, Geology, 35, 127-130, doi:10.1130/g23036a.1, 2007.

Smith, B. E., Fricker, H. A., Joughin, I. R., and Tulaczyk, S.: An inventory of active subglacial lakes in Antarctica detected by ICESat (2003-2008), J. Glaciol., 55, 573-595, 2009a.

Smith, J. A., Hillenbrand, C.-D., Larter, R. D., Graham, A. G. C., and Kuhn, G.: The sediment infill of subglacial meltwater channels on the West Antarctic continental shelf, Quaternary Res., 71, 190-200, 2009b.

Stokes, C. R. and Clark, C. D.: Palaeo-ice streams, Quaternary Sci. Rev., 20, 1437-1457, 2001.

Studinger, M., Bell, R. E., Blankenship, D. D., Finn, C. A., Morse, D. L., and Joughin, I.: Subglacial sediments: a regional geological template for ice flow in West Antarctica, Geophys. Res. Lett., 28, 3493-3496, 2001.

Sugden, D. and Denton, G.: Cenozoic landscape evolution of the Convoy Range to Mackay Glacier area, Transantarctic Mountains: Onshore to offshore synthesis, Geol. Soc. Am. Bull., 116, 840-857, doi:10.1130/b25356.1, 2004.

Sundal, A. V., Shepherd, A., Nienow, P., Hanna, E., Palmer, S., and Huybrechts, P.: Melt-induced speed-up of Greenland ice sheet offset by efficient subglacial drainage, Nature, 469, 521-524, doi:10.1038/nature09740, 2011.

Uenzelmann-Neben, G., Gohl, K., Larter, R. D., and Schlüter, P.: Differences in ice retreat across Pine Island Bay, West Antarctica, since the Last Glacial Maximum: indications from multichannel seismic reflection data, in: Antarctica: A Keystone in a Changing World - Proceedings for the Tenth International Symposium on Antarctic Earth Sciences, edited by: Cooper, A. K., Raymond, C. R., and the ISAES Editorial Team, US Geological Survey and The National Acadamies; USGS OF-2007-1047, Short Research Paper 084, 4 pp., 2007.
Vaughan, D. G., Corr, H. F. J., Ferraccioli, F., Frearson, N., O'Hare, A., Mach, D., Holt, J. W., Blankenship, D. D., Morse, D. L., and Young, D. A.: New boundary conditions for the West Antarctic Ice Sheet: Subglacial topography beneath Pine Island Glacier, Geophys. Res. Lett., 33, L09501, doi:10.1029/2005GL025588 2006.

Vaughan, D. G. and Arthern, R.: CLIMATE CHANGE: Why Is It Hard to Predict the Future of Ice Sheets?, Science, 315, 15031504, doi:10.1126/science.1141111, 2007.

Walder, J. and Fowler, A.: Channelized subglacial drainage over a deformable bed, J. Glaciol., 40, 3-15, 1994.

Weertman, J.: Stability of the junction of an ice sheet and an ice shelf, J. Glaciol., 13, 3-11, 1974.

Wellner, J. S., Lowe, A. L., Shipp, S. S., and Anderson, J. B.: Distribution of glacial geomorphic features on the Antarctic continental shelf and correlation with substrate: implications for ice behavior, J. Glaciol., 47, 397-411, 2001.

Wellner, J. S., Heroy, D. C., and Anderson, J. B.: The death mask of the antarctic ice sheet: Comparison of glacial geomorphic features across the continental shelf, Geomorphol., 75, 157-171, 2006.

Wilch, T. I., McIntosh, W. C., and Dunbar, N. W.: Late Quaternary volcanic activity in Marie Byrd Land: Potential 40Ar/39Ar-dated time horizons in West Antarctic ice and marine cores, Geol. Soc. Am. Bull., 111, 1563-1580, doi:10.1130/0016-7606, 1999.

Wingham, D. J., Ridout, A. J., Scharroo, R., Arthern, R. J., and Shum, C. K.: Antarctic elevation change from 1992 to 1996, Science, 282, 456-458, 1998.

Wingham, D. J., Siegert, M. J., Shepherd, A., and Muir, A. S.: Rapid discharge connects Antarctic subglacial lakes, Nature, 440, 1033-1036, 2006. 